\title{
Appraisal of social and health impact of a cement plant at host communities in Yandev, Nigeria
}

\author{
Fanan Ujoh $^{1, ~}$, Frederick Terkuma Ujoh ${ }^{2}$ \\ ${ }^{1}$ Department of Urban and Regional Planning, Benue State University, Makurdi, Nigeria \\ ${ }^{2}$ Faculty of Agriculture, University of Port-Harcourt, Choba, Nigeria
}

Email address:

fananujoh@gmail.com (F. Ujoh), terkumaujoh@gmail.com (F. T. Ujoh)

\section{To cite this article:}

Fanan Ujoh, Frederick Terkuma Ujoh. Appraisal of Social and Health Impact of a Cement Plant at Host Communities in Yandev, Nigeria. Science Journal of Public Health. Vol. 2, No. 4, 2014, pp. 275-283. doi: 10.11648/j.sjph.20140204.15

\begin{abstract}
Nigeria has extensive mineral and natural resources hence, developmental projects are being proposed and executed on a daily basis, many of which involve large-scale alteration of human, animal and plant ecosystems. Limestone mining and cement production commenced in 1980 at the study area, Yandev, without an environmental impact assessment to ascertain the extent of impact these activities could bring to bear on the physical and living conditions of the host environment. This study was carried out to appraise the social and health impact that mining of limestone and production of cement has inflicted on the host communities. Descriptive statistics and Kolmogorov-Smirnov test were used to analyse the primary data obtained. A total of 218 responses from 3 sampled ( 2 host and 1 control) communities, in addition to hospital records from 3 primary health centres, confirm severe health-related impacts of limestone mining and cement production on human populations at the host communities. The study concludes that the environmental compliance status of Dangote Cement Plc, Yandev towards attaining sustainability for the host communities as spelt by the Agenda 21 (Chapter 10, Objectives a \& c) is far from meeting the target requirement. The study recommends ameliorative measures including constant fumigation to control the proliferation of vector-based and zoonosis diseases; adoption of improved and cleaner production technologies, and relocation of communities away from the immediate vicinity of the factory.
\end{abstract}

Keywords: Social and Health Impact, Limestone Mining and Cement Production, Rapid Social Appraisals, Sustainability

\section{Introduction}

The African continent has extensive mineral and natural resources hence, developmental projects are being proposed and executed on a daily basis, many of which involve large-scale alteration of human, animal and plant ecosystems. For many of these projects, there are hardly any genuine EIA studies carried out [1]. The exploitation of these resources over the past few decades has left a vast wasteland of environmental problems. Because the socioeconomic development of any nation depends on the exploitation of her natural resources, both renewable and non-renewable [2], many therefore believe that these resources should be quickly exploited in order to develop and improve the under-nourished economy. In the face of accelerated development, many projects are carried out to extensive scales and for extended periods, with little or no concern for the environment. The need to reform resources development practices worldwide has recently become a key environmental issue in the efforts to establish a more "harmonious relationship between people and nature" [3].

In the past, international sustainability policies (such as Agenda 21) clamoured for the adoption of integrated approaches to planning and management of land and related natural resources. Specifically, some of the relevant objectives were to "review and develop policies to support the best possible use of land and the sustainable management of land resources, by not later than 1996", and to "create mechanisms to facilitate the active involvement and participation of all concerned, particularly communities and people at the local level, in decision-making on land use and management".

In sustainability assessment (SA), integrated impacts appraisals are designed to consider environmental, social and economic implications of projects, and to also examine the interrelations between these three pillars [4]. It is therefore, important to indicate that this study focuses on social (and health) pillar of SA. It is hoped that the 
disaggregation of these pillars (as exemplified in this study) would be more helpful in offering detailed insight into the impacts of existing resource utilization systems. The relevance of this study is instructive as there is increasing need to create baseline data for social and health impact status of the host communities of the Dangote Cement PLC, moreso as there was no environmental impact assessment (EIA) conducted over 30 years ago when the factory was established as Benue Cement Company Limited.

\section{Study Area}

The central location of Dangote Cement Plc, Yandev is at $7^{\circ} 24^{\prime} 42.45^{\prime \prime} \mathrm{N}$ and $8^{\circ} 58^{\prime} 31.28^{\prime \prime} \mathrm{E}$, with an elevation of 532 feet above mean sea level (Fig. 1). The area is generally located within a sub-humid tropical region with mean annual temperature ranging from $23^{\circ} \mathrm{C}$ to $34^{\circ} \mathrm{C}$, and is characterized by the dry and wet seasons. The mean annual precipitation is about $1,370 \mathrm{~mm}$, with an average wind speed of about $1.50 \mathrm{~m} / \mathrm{s}$, and average ambient air temperature of about $30^{\circ} \mathrm{C}$ [5]. The limestone reserves at the study area are of Cretaceous formation and in excess of 70 million tonnes [6].

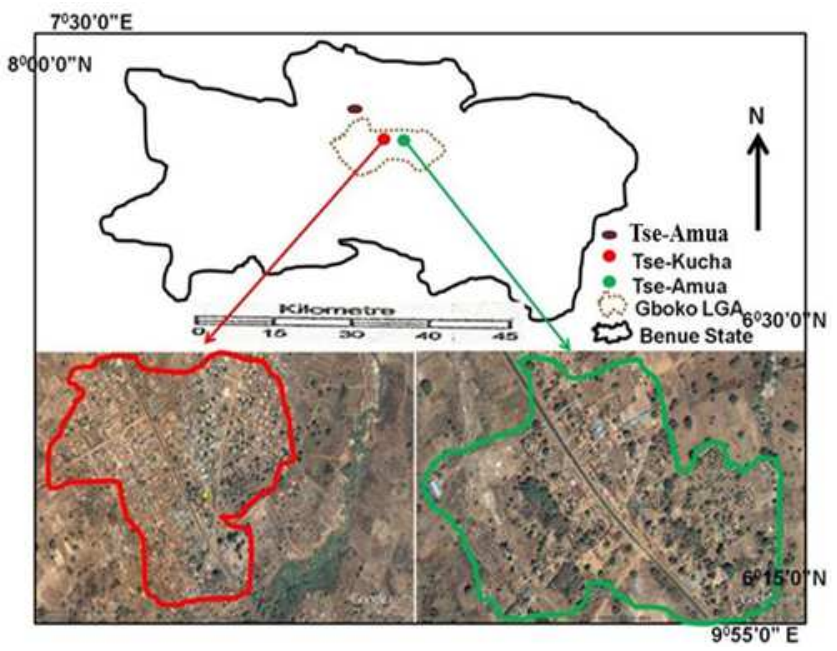

Fig. 1. Location of host and control communities

Within the study area, the most significant water bodies are two streams - 'Ahungwa' and 'Oratsor'. The Ahungwa stream is impounded to create a dam for use by the various production processes at the cement factory. The major kindreds within the 5-kilometre radius (comprising the area of interest to this study) include Mbaiwan, Mbatyula, Mbausu, Mbagar, Mbaataiwa and Mbawav, all of Mbatyu in Mbayion, Gboko LGA. However, the specific communities of interest to this study are the host communities, Tse-Kucha and Tse-Amua, and Tarhembe, the control community (Fig. 1). The inhabitants are largely preoccupied in traditional subsistence agriculture and wildlife hunting. Recently however, there has been a rise in small scale services such as restaurants, bars, beauty salons, mechanics, retailers of consumables, etc.

\section{Materials and Methods}

\subsection{General Research Framework}

The Rapid Assessment Procedure (RAP) forms the core research design adopted for the social impact appraisal of this study. The RAP employs both qualitative and quantitative data gathering techniques as both methods are required for RAP where time, funds and accessibility are issues to contend with.

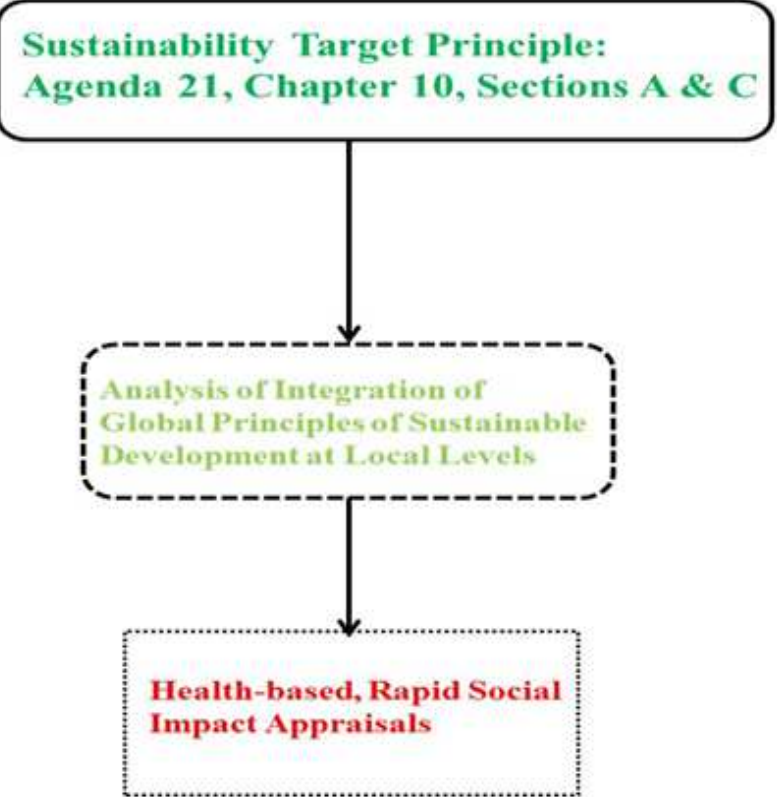

Fig. 2. Broad-based research approach (Model calibrated by authors using the provision in Agenda 21 document of UNCED)

The social and health based impact appraisal (Fig. 2) is carried out to extract information from key informants within study areas specifically on the health status of human, animal and plant populations at communities around development facilities. While the economic aspect of the host communities may or may not be considered, it is by no means regarded as less important. The focus on health-based effects is borne out of the correlation usually observed between the prevalence of air-borne diseases and industries with emissions such as the particulate matters found at most cement plants $[7 ; 8 ; 9]$.

\subsection{Data Sources}

A questionnaire was administered to members of two major host communities (Tse-Kucha and Tse-Amua, with proximity of less than 4 kilometers to the factory site) and one control community (Tarhembe located 12 kilometers away from factory site) to obtain their perception on the overall health impact of limestone mining and cement production on human, animal and plant populations at their communities. Medical records were also obtained from health centers at the host and control communities to investigate pattern of ailments within the area of interest. 


\subsection{Sample Frame Determination}

The study drew a sample size from the 2006 population figures of Gboko and Tarka LGAs (since communities' population figures from the 2006 census are yet available). The sample size was determined using a $0.05 \%$ of the total population of Gboko LGA which translates to a sample size of 179 persons for Tse-Kucha and Tse-Amua communities. This figure was divided fairly equally ( 90 for Tse-Kucha and 89 for Tse-Amua) between the two host communities. The choice of these communities was based on the fact that they are the two most prominent settlements located near the factory site. The random sampling technique was adopted to identify households within the communities for questionnaire administration. Tarhembe, the control community, is located in Tarka LGA. Using $0.05 \%$ of the total population of Tarka LGA $(79,494$ according to the 2006 Population Census), a sample size of 39 respondents was determined while questionnaire administration was done by the application of the random sampling method within the community.

\subsection{Questionnaire Design and Administration}

The questionnaire was designed to collect data and provide adequate information to study the social impact objective of the research. The aim is to provide meaningful answers to the specific research question focusing on health-based impact of limestone mining and cement production on host communities at Yandev. The questionnaire contains mostly Likert-format questions in order to establish the extent or degree of agreement or otherwise to factors of interest to the study. The questionnaire was also designed using simple language to avoid ambiguity and mis-conceptions. This was considered necessary as the simplicity and flexibility of the questionnaire allowed for a hassle-free survey exercise where the target population is rural in nature and mostly less literate.

A questionnaire was thus, administered to a total of 218 respondents on a 'one-on-one' basis. The essence was to explain any section in the questionnaire that appeared confusing to respondents and also to ensure that the expected rate of duly filled and returned questionnaire was achieved. Also, all questionnaire administration was done only to natives of the two study communities. This was done under the assumption that established and older members of the communities would possess more valuable information about the problems of interest to the study than transient persons. During the initial field survey, it was observed that the structure of development within the communities was not orderly, thus it was difficult to present a consistently orderly, random pattern of survey. However, deliberate efforts were made during questionnaire administration to ensure randomness while equally ensuring that the target population was maintained and reached.

With the aid of 2 field assistants over a period of 13 days, the questionnaire administration process was completed with a $100 \%$ return rate at all 3 communities. Further information was gathered through informal interactions with the communities' members during the survey period.

\subsection{Data Analyses}

The Kolmogorov-Smirnov (K-S) test was adopted for this study. It is a non-parametric test for equality of continuous, one-dimensional probability distributions that can be used to compare a sample with a reference probability distribution. The choice of the test is based on its ability to be modified to serve as a goodness of fit test. Descriptive statistics were generated and a one-sample K-S test analysis was also carried out. The underlying principle behind this technique is driven by the fact that besides attempting to predict populations' perceptions, it is suitable for conducting analysis on relatively small sample sizes [10]. In addition, it facilitates a simultaneous analysis of whether the hypothesized relationships at the theoretical level are empirically confirmed. Therefore, the K-S is preferred for analyses of exploratory models where explanation of the construct inter-relationship is desired.

The test is based on the empirical cumulative distribution function (ECDF).

Given $\mathrm{N}$ ordered data points $\mathrm{Y} 1, \mathrm{Y} 2, \ldots \ldots . \mathrm{YN}$, the ECDF is defined as:

$\mathrm{EN}=\mathrm{n}(\mathrm{i}) / \mathrm{N}$

Where;

$n(i)=$ number of points less than Yi (Yi are ordered from smallest to largest values).

The descriptive and K-S test techniques together provide a description of the basic features and simple summaries about the sample and the measures. Hence, collectively, these techniques provide a good description and clear understanding of what the quantitative data for this study shows.

\section{Results and Discussions}

\subsection{Demographic and Socio-economic Composition of Respondents}

In all, the study population consisted of more males (72.5\%) than females (27.5), across all age categories in all 3 sampled communities (Fig. 3). The only plausible explanation is the ease with which access to holding a discussion with a male can be obtained as against a female, particularly in the rural areas of Tivland where culture readily permits the men to meet with strangers except in cases where men are unavailable.

The educational status of respondents (Fig. 4) reveal that about $13.3 \%$ of the respondents did not attend any formal educational institution, while primary and secondary educational attainment is about $22.5 \%$ and $49.1 \%$, respectively. For tertiary education, the attainment level is $15.1 \%$. Education (literacy) is an index that is often incorporated in measuring the well-being and level of 
development of a population. Thus, the population of study can be rated as generally average in its effort toward renewing and improving its future reservoir of skills and general abilities $[11 ; 12 ; 13 ; 14]$. The reason is not farfetched as the study communities are located close to Gboko town which, according to Ujoh et al., [14], has the highest number of secondary and tertiary educational facilities within Benue State.

The occupational mix of the respondents (Fig. 5) shows that there are more farmers $(32 \%)$ within the sampled communities than any other livelihood activity with wage earners (or paid employment including those working at the factory and Local Government establishments which amounts to $7 \%$ ) being the least source of livelihood for community members. The 'Others' category is defined to include students, the unemployed and other service-related jobs such as barbers, bar tenders and restaurant stewards, etc. Further inquiries revealed that there has been very minimal increment in job opportunities from the cement factory even to the 2 host communities. However, responses indicate an increase in non-formal, services work opportunities such as artisans, bars and restaurants stewards, etc., especially at Tse-Kucha community which is closest to the factory.

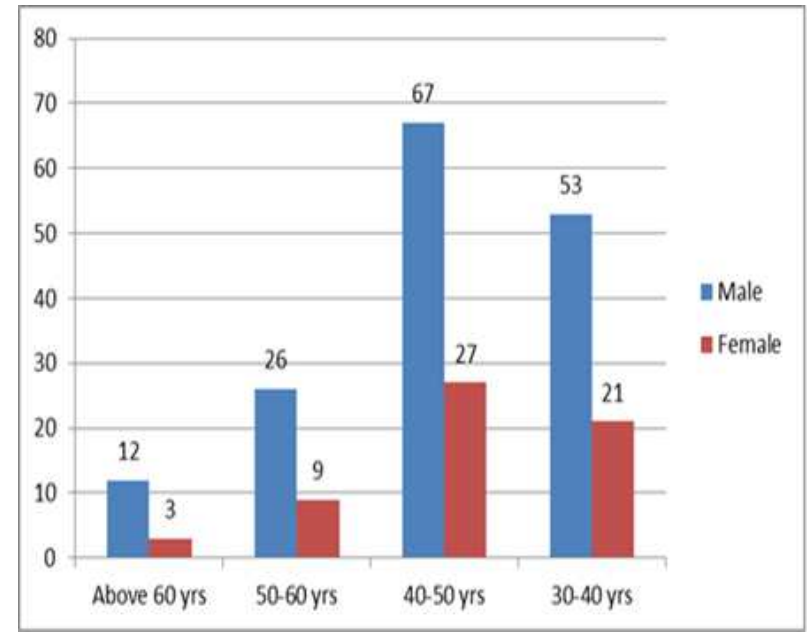

Fig. 3. Sex-Age Distribution of respondents

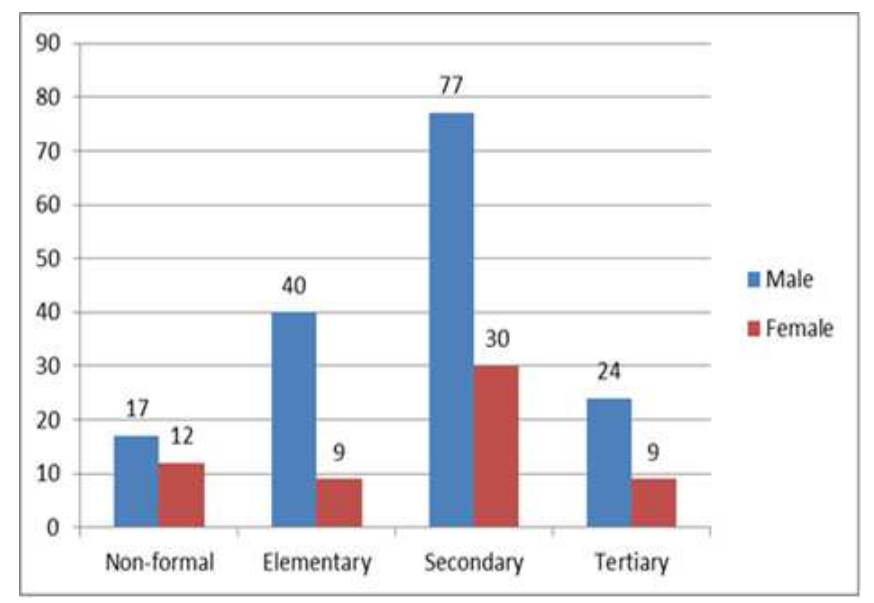

Fig. 4. Educational level of respondents

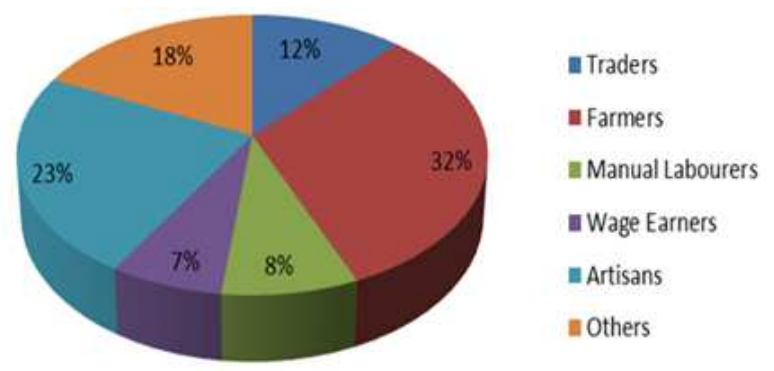

Fig. 5. Occupational status of respondents

\subsection{Social and Health Impact Appraisals}

The study identified several key sampling parameters on the likely impacts of limestone mining and cement production at Yandev (Table 1) using the Likert-format of inquiry. The sample population at the host communities, Tse-Kucha and Tse-Amua, and at Tarhembe, the control community, responded to the likelihood of these listed impacts. Figure 6 reveal that responses are opposing between the host and control communities. While the respondents at Tse-Kucha and Tse-Amua affirmed to severe impacts of limestone mining and cement production, those at Tarhembe were differing in their responses. In all, over $90 \%$ of responses from the 2 host communities affirmed to the activities of the cement plant's impact on human, animal and plant population within their communities, whereas over $66 \%$ of the respondents at the control community confirmed there are no impacts of the factory's activities at their community.

It was also understood that high incidence of air-borne diseases are recorded within the study area. Table 2 shows records of medical cases at three Primary Health Centres, one each from the 3 study communities. Medical records could only be obtained for 9 years (between 2004 and 2012) from the host communities, and for only 5 years from the Health Centre at the Control community. Medical records at the Control community were not as updated as those from the host communities. However, the medical cases recorded at the host communities are higher in proportion than those recorded at the Control community.

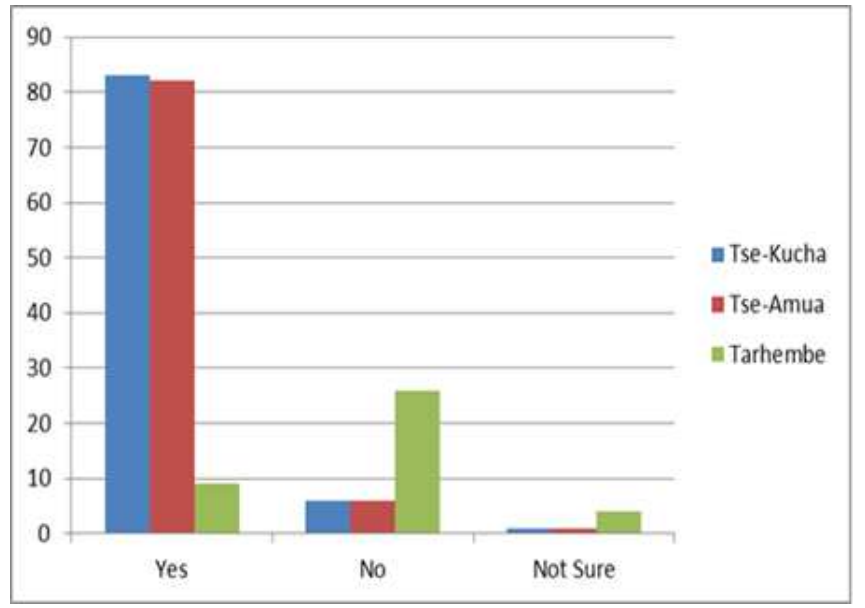

Fig. 6. Impact of plume on communities 
Although the trend of occurrence of medical cases appears rather fluctuating (rising in some years and declining in others), these ailments recorded are largely airborne and have been linked to pollutants possibly arising from activities around plants as proven in other studies by $[8 ; 15 ; 16 ; 17 ; 18]$. Some of these ailments have been listed in Table 3.

Due to poor medical facilities at the primary health centres, most of the illnesses listed above could not be clearly diagnosed. The medical staff informed that their classification of these illnesses was based on the symptoms observed from patients. In some cases, community members with severe health cases were taken to various more equipped hospitals away from these communities since it is common knowledge that these health centres are poorly equipped. Therefore, it is possible that number of cases for complicated illnesses could have been more than recorded by the clinics.

\subsection{Statistical Analyses of Social and Health Impacts}

Table 4 presents the summary of raw data collected from the field survey. It appears the only point of convergence between all communities is in the issue of Community Social Responsibility (CSR) activities, which is recorded in the negative. The raw data on Table 4 is further subjected to the Kolmogorov-Smirnov (K-S) probability distributions test. The results show variation between the means and standard deviation of all responses (Table 5), with the 'strongly disagree' and 'strongly agree' options exhibiting the highest values for mean and standard deviation. This reveals the extreme responses arising from differing health conditions between the host and control communities. Whereas responses from the host communities strongly agree with most of the health impact checklists, reverse is the case with majority of the responses from the control community.

In statistical terms, Table 5 also shows that test results of all 5 responses of the calculated asymptotic significance values exceed 0.05 , implying that the test result is not significant. For the K-S test, the results indicate that the research data tested is normally distributed. It therefore, implies that there is a significant difference in the human, animal and plant health impact between host communities (Tse-Kucha and Tse-Amua) and the control community (Tarhembe). The former is adversely impacted while the latter is not adversely impacted.

Most of the responses revealed high level of awareness of the health impacts of cement dust on human, plant and animal populations within the study communities (see Figure 6). During discussions, it was clearly stated that a pattern of death occurrences involving a significant number of those who had previously worked in the factory's manual loading bay (before it became automated upon acquisition by Dangote Cement Plc.). This is consistent with findings from similar research works on effects of cement dust on human health (see also Table 3). These include ailments such as lung malfunction/impairment; chronic obstructive and restrictive lung diseases; pneumoconiosis and carcinoma of the lungs, stomach and colon; in addition to the fact that cement dust is capable of reaching all organs of body thereby affecting the different tissues such as heart, liver, spleen, bone, muscles and hairs and ultimately affecting their micro-structure and physiological performance $[15 ; 16 ; 19 ; 20 ; 21]$.

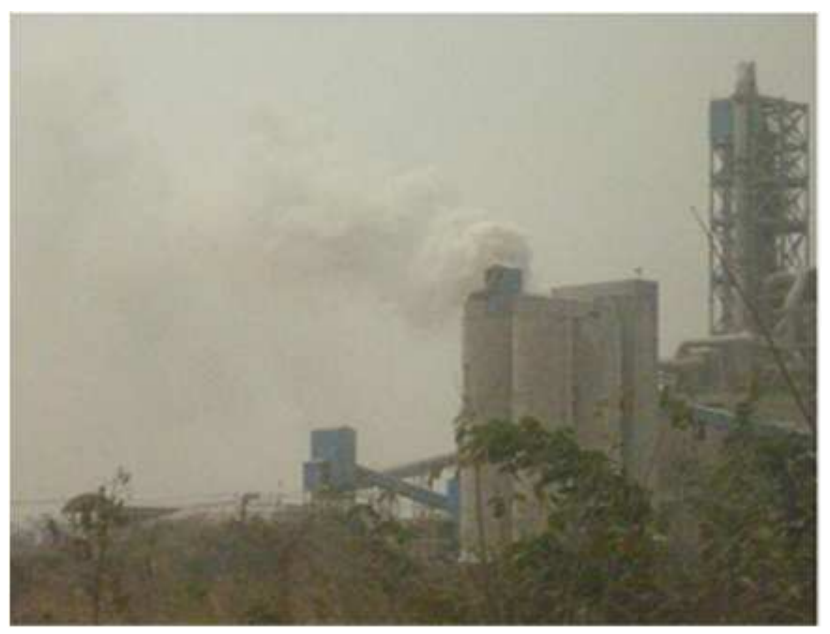

Plate 1. Plume emission at study area (06:01:2011 at dawn)

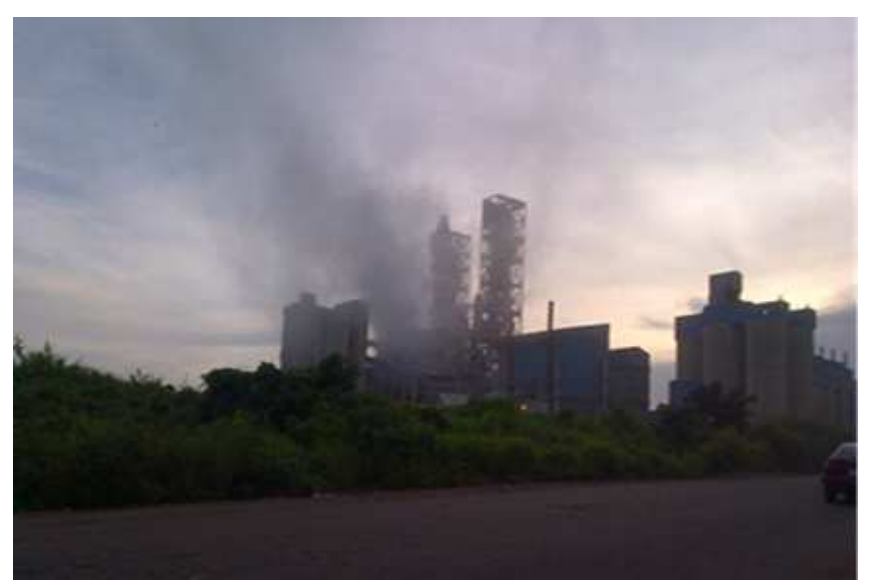

Plate 2. Plume emission at study area (28:08:2012 at dusk)

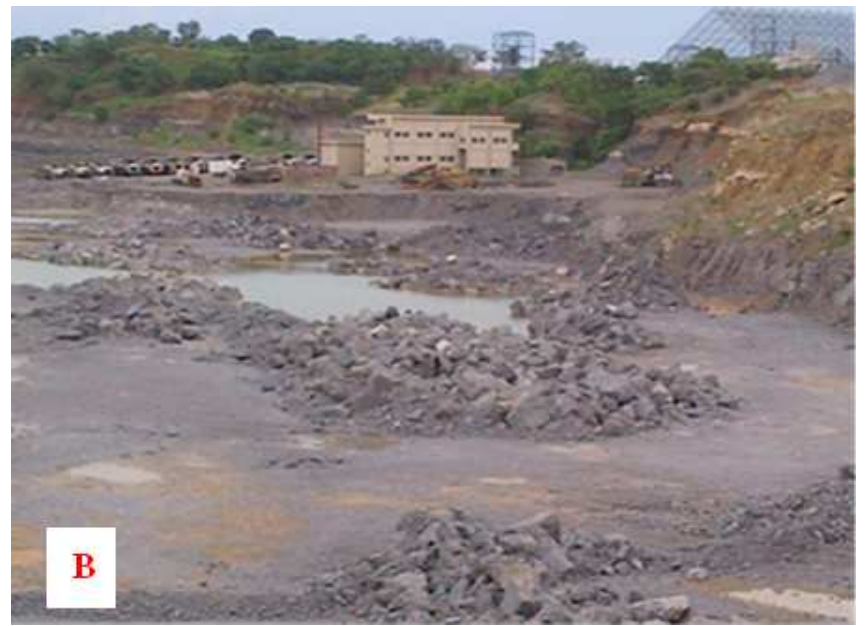




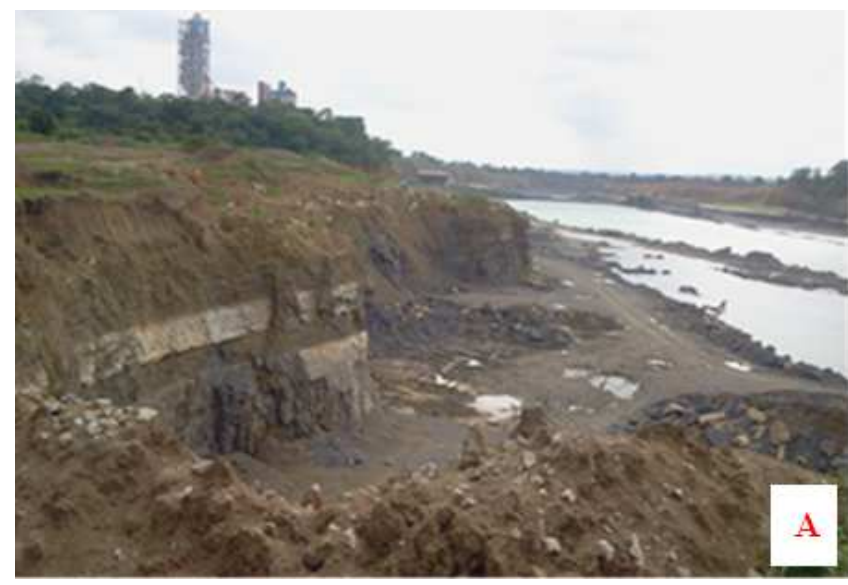

Plate $3(\boldsymbol{a} \& \boldsymbol{b})$. Land degradation at limestone mine site

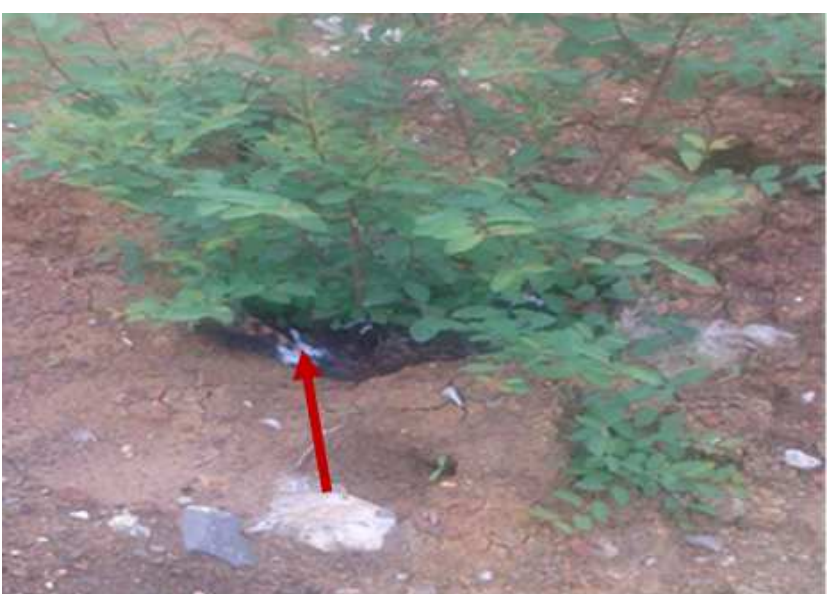

Plate 4. A bird found dead (arrowed) in its habitat less than a kilometer from factory site

Table 1. Cases of Diseases Recorded at Host and Control Communities

\begin{tabular}{|c|c|c|c|c|c|}
\hline \multirow[b]{2}{*}{ Year } & \multicolumn{5}{|c|}{ Ailments } \\
\hline & $\begin{array}{l}\text { Respiratory: Lungs, } \\
\text { Oral cavity, Liver, etc. }\end{array}$ & Gastro-intestinal & $\begin{array}{c}\text { *Central nervous } \\
\text { system }\end{array}$ & Malaria & $\begin{array}{l}\text { Miscellaneous: Eyes, } \\
\text { skin, bones, etc. }\end{array}$ \\
\hline \multicolumn{6}{|c|}{ Host Communities } \\
\hline 2004 & 81 & 910 & NA & 1,945 & 2,610 \\
\hline 2005 & 107 & 876 & NA & 2,097 & 2,378 \\
\hline 2006 & 72 & 942 & NA & 1,860 & 2,974 \\
\hline 2007 & 99 & 1,190 & NA & 3,103 & NA \\
\hline 2008 & 180 & 1,115 & NA & 3,198 & NA \\
\hline 2009 & 172 & 1,400 & NA & 2,897 & 4,007 \\
\hline 2010 & 89 & 1,390 & NA & 4,079 & 4,126 \\
\hline 2011 & 119 & 1,608 & NA & 4,219 & NA \\
\hline 2012 & 188 & 1,699 & NA & 4,376 & 7,172 \\
\hline \multicolumn{6}{|c|}{ Control Community } \\
\hline 2007 & 24 & 89 & NA & 313 & 19 \\
\hline 2008 & NA & NA & NA & NA & NA \\
\hline 2009 & 29 & 127 & NA & 386 & 64 \\
\hline 2010 & 41 & 119 & NA & 679 & 91 \\
\hline 2011 & 39 & 196 & NA & 437 & 82 \\
\hline$* * 2012$ & 28 & 92 & NA & 396 & 73 \\
\hline
\end{tabular}

NA - Not available. ** Records available for only 9 months.

Source: Medical Records, Health Centres at Tse-Kucha, Tse-Amua and Tarhembe.

Table 2. Diseases Caused by Cement Dust

\begin{tabular}{|c|c|c|c|}
\hline S/No. & System & Organ & Effect \\
\hline 1 & Respiratory & Lungs & $\begin{array}{l}\text { Cough and phlegm production, chest tightness, impairment of lung function, obstructive } \\
\text { and restrictive lung disease, Pleural thickening, fibrosis, emphysema, lung nodulation, } \\
\text { pneumoconiosis and carcinoma of lung. }\end{array}$ \\
\hline 2 & & Oral Cavity & $\begin{array}{l}\text { Mechanical trauma, mucosal inflammation, loss of tooth surface, periodontal disease, } \\
\text { dental abrasion and dental caries. }\end{array}$ \\
\hline 3 & Gastro-Intestinal & Liver & $\begin{array}{l}\text { Diffuse swelling and proliferation of sinusoidal (hepatic) lining cells, sarcoid type } \\
\text { granulomas, perisinusoidal and portal fibrosis and hepatic lesions. }\end{array}$ \\
\hline 4 & & Stomach & Stomach ache and cancer of stomach \\
\hline 5 & Central Nervous & Brain & Headaches and fatigue \\
\hline 6 & Lymphatic & Spleen & Diminished lymphatic tissues and splenic lesions \\
\hline 7 & Miscellaneous & Eye, Skin and Bone & $\begin{array}{l}\text { Irritation of eyes, runny eyes and conjunctivitis, skin irritation, itching, skin boil and burn, } \\
\text { osteonecrosis, lesion of the humerus, thinning of the cortex and reduction of epiphyseal } \\
\text { cartilage. }\end{array}$ \\
\hline
\end{tabular}


Table 3. Tested Parameters for Health Impact at Host and Control Communities

\begin{tabular}{|c|c|c|c|c|c|c|}
\hline Identified Impacts & $\begin{array}{c}\text { Strongly } \\
\text { Agree } \\
\text { (SA) } \\
\end{array}$ & $\begin{array}{l}\text { Agree } \\
\text { (A) }\end{array}$ & $\begin{array}{c}\text { Slightly } \\
\text { Disagree } \\
\text { (SD) } \\
\end{array}$ & $\begin{array}{l}\text { Disagree } \\
\text { (D) }\end{array}$ & $\begin{array}{c}\text { Strongly } \\
\text { Disagree } \\
\text { (S) } \\
\end{array}$ & Row Total \\
\hline Dust emission from cement production & 127 & 33 & 19 & 13 & 26 & 218 \\
\hline Removal of vegetal cover due to limestone mining & 60 & 58 & 20 & 29 & 51 & 218 \\
\hline $\begin{array}{l}\text { High noise levels during limestone blasting and cement } \\
\text { production operations }\end{array}$ & 71 & 37 & 15 & 57 & 38 & 218 \\
\hline Impacts associated with blasting & 98 & 57 & 13 & 11 & 39 & 218 \\
\hline $\begin{array}{l}\text { Impacts associated with mine water discharge, liquid } \\
\text { effluents and change of water quality }\end{array}$ & 80 & 39 & 29 & 18 & 52 & 218 \\
\hline Social tension due to increased population flux & 20 & 80 & 48 & 12 & 58 & 218 \\
\hline Increased vector-derived diseases (e.g. malaria) & 39 & 67 & 46 & 31 & 35 & 218 \\
\hline Impact of plume deposition on plants and animals & 39 & 103 & 30 & 19 & 27 & 218 \\
\hline $\begin{array}{l}\text { Impact of plume on human health / increase in cases of } \\
\text { respiratory and or airborne diseases }\end{array}$ & 29 & 79 & 55 & 33 & 22 & 218 \\
\hline $\begin{array}{l}\text { Increased road traffic hazards due to truck/vehicle } \\
\text { movement }\end{array}$ & 140 & 61 & 7 & 6 & 4 & 218 \\
\hline Conflicts due to loss of agricultural land and produces & 25 & 18 & 1 & 39 & 135 & 218 \\
\hline Compensation regularly paid & 13 & 15 & 48 & 32 & 110 & 218 \\
\hline Active CSR at communities & 0 & 0 & 4 & 50 & 164 & 218 \\
\hline Column Total & 741 & 647 & 335 & 350 & 761 & 2,834 \\
\hline
\end{tabular}

Table 4. Descriptive Statistics

\begin{tabular}{|c|c|c|c|c|c|}
\hline Likert-type Responses & $\mathbf{N}$ & Mean & Std. Deviation & Minimum & Maximum \\
\hline Strongly Agree & 13 & 57.000 & 43.98295 & .00 & 140.00 \\
\hline Agree & 13 & 49.7692 & 29.43964 & .00 & 103.00 \\
\hline Slightly Disagree & 13 & 25.7692 & 18.43526 & 1.00 & 55.00 \\
\hline Disagree & 13 & 26.9231 & 15.59092 & 6.00 & 57.00 \\
\hline Strongly Disagree & 13 & 58.5385 & 47.81669 & 4.00 & 164.00 \\
\hline
\end{tabular}

Table 5. One-Sample Kolmogorov-Smirnov Test

\begin{tabular}{|c|c|c|c|c|c|c|c|}
\hline & & & SA & $\mathbf{A}$ & SD & D & $\mathbf{S}$ \\
\hline $\mathrm{N}$ & & & 13 & 13 & 13 & 13 & 13 \\
\hline \multirow[t]{2}{*}{ Normal Parameters(a,b) } & Mean & & 57.0000 & 49.7692 & 25.7692 & 26.9231 & 58.5385 \\
\hline & Std. Deviation & & 43.98295 & 29.43964 & 18.43526 & 15.59092 & 47.81669 \\
\hline \multirow[t]{3}{*}{ Most Extreme Differences } & Absolute & & .197 & .135 & .171 & .156 & .274 \\
\hline & Positive & & .197 & .104 & .161 & .156 & .274 \\
\hline & Negative & & -.098 & -.135 & -.171 & -.091 & -.145 \\
\hline Kolmogorov-Smirnov Z & & & .711 & .488 & .618 & .562 & .987 \\
\hline Asymp. Sig. (2-tailed) & & & .692 & .971 & .839 & .910 & .284 \\
\hline \multirow[t]{3}{*}{ Monte Carlo Sig. (2-tailed) } & Sig. & & $.624(\mathrm{c})$ & $.947(\mathrm{c})$ & $.780(\mathrm{c})$ & $.863(\mathrm{c})$ & $.237(\mathrm{c})$ \\
\hline & $\begin{array}{l}99 \% \text { Confidence } \\
\text { Interval }\end{array}$ & Lower Bound & .612 & .942 & .769 & .854 & .226 \\
\hline & & Upper Bound & .637 & .953 & .790 & .872 & .248 \\
\hline
\end{tabular}

a) Test distribution is Normal. b) Calculated from data. c) Based on 13 sampled tables.

\section{Conclusion}

Changes at the micro-climatic levels endanger human health, affecting all sectors of society. The environmental consequences of climate change (both those already observed and those that are anticipated including heat waves and warmer temperatures and degraded air quality) will affect human health directly and/or indirectly [22] at local and regional levels. Addressing the effects of climate change on human health is especially challenging because both the surrounding environment and the decisions that people make influence health [23]. 
The increasingly warm environment and presence of stagnant water from the large mining ponds at the study area [9] as clearly shown in Plates 1-4 implies that the human population of the host communities is directly susceptible and vulnerable to vector borne and zoonotic diseases (VBZD). Although valid projections on likely impacts of warmer conditions may be lacking due to nonemergence of a scientific consensus, it has been reasonably argued that malaria (a major VBZD) thrives unimpeded at locations with similar deteriorating physical and environmental conditions [24]. Already, a significant proportion of the sampled population and clinic records reveal increasing cases of malaria within the study area. Additionally, there are health related problems at the host communities that are yet properly documented, let alone attempting a resolution process.

In Nigeria, the legal and regulatory framework for mineral exploration and environmental management is highly centralized with the Federal and State governments primarily responsible for developing and applying the legislative framework, including the provision of supervisory and regulatory functions. By implication, the Local Government Areas (LGAs) are not empowered to enact, repeal or otherwise revise any legislation apart from local by-laws. However, it is becoming apparent that the problems created at the local levels (through the nationalbased legal and regulatory frameworks) can better be resolved by the active inclusion of locally-derived practicable solutions based on action-planning. The prevailing environmental conditions at the study area would, as a matter of practicality, require the attention and willed intervention of the Federal and State tiers of government, with the LGA championing the process. This could require reformation backed by legislation, a process that could likely be delayed beyond a short term timeframe.

In the meantime, short term measures could be instituted to relocate communities away from the immediate vicinity of the factory; to conduct fumigation of the area against VBZD; and to also reduce drastically plume emissions through improved and cleaner cement production processes. Finally, it is indeed apparent that a standardized form of periodic but consistent investigation into the socioenvironmental status of the host communities be instituted.

\section{Acknowledgements}

The authors are grateful to Comrade Iortyer Gyenkwe and Mr. Solomon Ukor for their assistance during fieldwork.

\section{References}

[1] A.O. Arimoro, M.A. Fagbeja and W. Eedy: "The Need and Use of Geographic Information Systems for Environmental Impact Assessment in Africa: With Examples from Ten Years' Experience in Nigeria. AJEAM/RAGEE, Vol. 4, No. 2. pp 16-27, 2002
[2] National Environmental Management Authority, "Environmental Management Tools- Uganda". African Impact Assessment, 2001.

[3] R.F. Noss and A.Y. Cooperrider, "Saving Nature's Legacy. Protecting and Restoring Biodiversity". Island Press, Washington D.C., 1994

[4] J. Pope, A. Bond, A. Morrison-Saunders and F. Retief. "Advancing the Theory and Practice of Impact Assessment: Setting the Research Agenda". Environmental Impact Assessment Review, Vol. 41, pp. 1-9, 2013.

[5] National Meteorological Agency NIMET. "Climatic Data". Retrieved from NIMET Office, Makurdi, Nigeria; 2012.

[6] R. Lal. "Soil erosion and its relation to productivity in tropical soils". Malma Aina Conf. Honolulu, Hawaii, 16-22 January 1983.

[7] M.D. Adak, S. Adak and K.M. Purohit. "Ambient air quality and health hazards near mini cement plants." Pollution Research, Vol. 26, No. 3, pp. 361-364, 2007.

[8] B.A. Ikyo, A.A. Akombor and T. Igbawua, "Determination of Ground Level Concentration of Pollutants from the Benue Cement Company (BCC) Plc, Gboko, Nigeria: A Mathematical Approach". Journal of Research in Physical Sciences, Vol. 3, No. 4, pp. 35-42, 2007.

[9] F. Ujoh. "An Assessment of the Environmental Impact of Limestone Mining and Cement Production at Yandev, Nigeria". PhD Thesis, Department of Geography and Environmental Management, University of Abuja, Nigeria, 2014.

[10] C. Cassel, P. Hackl and A.H. Westlung, "Robustness of Partial Least Squares Method for Estimating Latent Variable Quality Structures," Journal of Applied Statistics, Vol. 26, No. 4, pp. 435-446, 1999.

[11] P.E. Lloyd and P. Dicken, "Location in Space: A Theoretical Approach to Economic Geography". Harper and Row, New York, 1972.

[12] A.O. Ozigi and L. Ocho, "Education in Northern Nigeria". George Allen and Unwin, London; 1981.

[13] O. Balogun, "Diffusion of Post primary Schools in Kwara State". The Abuja Journal of Economics and Social Studies Seminar, Vol. 30, No. 3, pp 335-349, 2000.

[14] F. Ujoh, O.O. Ifatimehin and E.D. Jenkwe. "Analysis of the Spatial Diffusion of Post-Primary Schools in Benue State, 1915-2002". Journal of Technology and Education in Nigeria, Vol. 13, Nos. 1\& 2, pp. 1-11, 2009.

[15] S.A. Meo, M.A. Azeem, M.G. Ghori and M.M.F. Subhan, "Lung function and Surface electromyography of intercostals muscles in cement mill workers”. Int. J. Occup. Med and Environ. Health, Vol. 15, pp. 279-287, 2002.

[16] S.A. Meo, "Chest radiological findings in Pakistani cement mill workers”. Saudi Med. J., Vol. 24, pp. 287-290, 2003.

[17] A.O. Akeem, "Impact of Ewekoro Cement Factory on the Surrounding Water Resources". Bachelor of Water Resources and Hydrology Management Research Project, Federal University of Agriculture, Abeokuta, Nigeria, 2008. 
[18] H. Ahiamadjie, O.K. Adukpo, J.B. Tandoh, O. Gyampo, M. Nyarku, I.I. Mumuni, O. Agyemang, M. Ackah, F. Otoo, and S.B. Dampare, "Determination of the Elemental Contents in Soils Around Diamond Cement Factory, Aflao: Research Journal of Environmental and Earth Sciences 3(1): 46-50, 2011.

[19] Y.I. Al-Neaimi, J. Gomes and O.L. Lloyd, "Respiratory illnesses and ventilatory function among workers at a cement factory in a rapidly developing country." Occupational Medicine Vol. 51, No.6, pp. 367-373, 2001.

[20] S. Aydin, S, Aydin, G. Croteau, I. Sahin and C. Citil, "Ghrelin, Nitrite and Paraoxonase/Arylesterase Concentrations in Cement Plant Workers." Journal of Medical Biochemistry, Vol. 29, No. 2, pp. 78-83., 2010.

[21] Z. Zeleke, B. Moen and M. Bratveit, "Cement Dust Exposure and Acute Lung Function: A Cross Shift Study." BMC Pulmonary Medicine, Vol. 10, No. 1:19, 2010.
[22] V.S. Singh and D.N. Pandey, "Human Health Risk due to Cement Dust Exposure. Policy-Brief, Climate Change and CDM Cell", Rajasthan State Pollution Control Board, Jaipur, India, 2011.

[23] Environmental Health Perspectives EHP \& National Institute of Environmental Health Sciences NIEHS. "A Human Health Perspective on Climate Change: A Report Outlining the Research Needs on the Human Health Effects of Climate Change". April 22, 2010. Available online at http://www.niehs.nih.gov/health/assets/docs_a e/climaterep ort2010.pdf Accessed 20 August 2012

[24] O.O. Ifatimehin and F. Ujoh, "Application of Remotelysensed Data for Modelling Malaria Infection in Lokoja, Nigeria". International Journal of Tropical Diseases \& Health, Vol. 4, No. 6, pp. $634-644,2014$. Available online at: http://www.sciencedomain.org/issue.php?iid=465\&id=19 